\title{
Improving the shelf life of chicken burgers using Octopus vulgaris and Dosidicus gigas skin pigment extracts
}

\author{
Dania Marisol ESPARZA-ESPINOZAㅜ, Maribel PLASCENCIA-JATOMEA ${ }^{1}$, Carmen María LÓPEZ-SAIZ, \\ Norma Violeta PARRA-VERGARA ${ }^{1}$, Angel Antonio CARBONELL-BARRACHINA ${ }^{2}$, José CÁRDENAS-LÓPEZ ${ }^{1}$, \\ Josafat Marina EZQUERRA-BRAUER ${ }^{1 *}$ (D)
}

\begin{abstract}
In this work, an innovative strategy for raw chicken burger preservation, based on methanol-HCl extracts of octopus (Octopus vulgaris) (OVE) and squid (Dosidicus gigas) (DGE) skin pigments, was evaluated at $4{ }^{\circ} \mathrm{C}$ for 12 days. Burgers were prepared and divided into six groups: the control without any extract (CON), the control with $0.03 \%$ a-tocopherol (CET), and those containing 0.05\% (OVE1, DGE1) and 0.1\% (OVE2, DGE2) octopus and squid pigment extract, respectively. OVE yielded a higher rate of pigments with antioxidant activity (DPPH, ABTS, and ORAC) than DGE. The highest antimutagenic activity was detected in DGE according to the Ames' Salmonella test. OVE1 and DGE1 burgers maintained lower $\mathrm{pH}$ values and were less sensitive to lipid oxidation (peroxide, anisidine, and total oxidation values). Evaluation of microbial growth by total bacterial count, lactic acid bacteria, Enterobacteriaceae spp., and fungi showed that OVE1 and DGE1 delayed bacterial contamination. The overall sensory quality was maintained for longer in the OVE- and DGE-supplemented chicken burgers than CON burgers. This study showed that OVE and DGE have potential as antioxidant and antimicrobial additives in chicken products.
\end{abstract}

Keywords: antioxidant activity; antimicrobial activity; chicken burger; cephalopod pigments.

Practical Application: Improved chicken burger storage stability using cephalopod skin pigments. Significant opportunities exist in using cephalopod skin to create new beneficial products for customers.

\section{Introduction}

Chicken meat products are favored by consumers around the world because of their composition and health benefits (Zhang et al., 2016). Among the various culinary types of chicken meat, burgers are one of the most common (Ramsing, 2020). Various factors are associated with increased in consumption of chicken burgers, such as their high nutritional value and attractive sensory attributes (Ramsing, 2020). Nonetheless, the minced muscle used in chicken burgers is more vulnerable to peroxidation and microbial growth due to disruption of the cellular components induced by the grinding process. Oxidative reactions and spoilage lead to the shorter shelf life of the products, producing a financial burden (Zhang et al., 2016). Different preservative compounds have been used to prevent deterioration of quality during the storage of raw chicken meat products (Aziz \& Karboune, 2018).

Synthetic antioxidants and antimicrobials are highly effective. However, there is uncertainty regarding their negative impacts on human health. Because health labels (indicating virtually artificial additive-free foods) are demanded and preferred by consumers (Aryee \& Boye, 2014), food research has been focused on replacing synthetic additives with natural compounds (Kumar et al., 2017). Among these natural additives, seafood by-products can be used to improve the shelf life of foods. Unlike synthetic compounds, natural preservatives obtained from seafood by-products are rich in different kinds of compounds that can enhance the overall quality of food by decreasing lipid oxidation and microbial growth (Shahidi et al., 2019).

Among seafood by-products, cephalopod skin pigments have been studied as an alternative to synthetic antioxidants or preservatives (Aubourg et al., 2016; Ezquerra-Brauer et al., 2016, 2017; Chan-Higuera et al., 2019a, b). Furthermore, no toxic effect was detected in such pigments (Ezquerra-Brauer et al., 2017, Chan-Higuera et al., 2019b). These pigments most likely have antioxidant and antimicrobial activity because they are ommochromes (Chan-Higuera et al., 2019c), which are the main products of the metabolic oxidation pathway of tryptophan. Their basic structure consists of a phenoxazine ring with different substituents (Daniels \& Reed, 2012). Ommochromes can act as antioxidants through their chelating activity and acting as primary antioxidants by scavenging radicals such as singlet oxygen and superoxide anions (Ostrovsky et al., 1987). Moreover, the different substituents present in the phenoxazine ring can act as electron donors and could be responsible for inducing an imbalance in the metabolic pathways of microorganisms (Romero \& Martínez, 2015).

${ }^{1}$ Departamento de Investigación y Posgrado en Alimentos - DIPA, Universidad de Sonora - UNISON, Hermosillo, Sonora, Mexico.

${ }^{2}$ Departamento de Tecnología Agroalimentaria, Escuela Politécnica Superior de Orihuela - EPSO, Universidad Miguel Hernández de Elche - UMH, Orihuela, Alicante, Spain.

*Corresponding author: josafat.ezquerra@unison.mx, josafatmarina@gmail.com 
On the other hand, besides exploring natural compounds that can replace artificial additives, food scientists have investigated the potential of these compounds to act against the development of illnesses. Antioxidant and antimutagenic activity has been broadly considered as promising factor in preventing the development of chronic degenerative diseases mediated by the production of free radicals (Peng et al., 2014). Thus, many natural antioxidant compounds have been evaluated as antimutagenic components. However, information about the effects of cephalopod skin pigment extracts on mutagenic activity are scarce.

The present study includes the first attempt to use cephalopod skin pigments as innovative bioactive and preservative compounds in a chicken burger product during refrigerated storage. The fundamental objective was to investigate the effects of adding octopus and squid skin pigments individually to raw chicken burgers. For this study, two different concentrations of ommochrome pigment extracts were tested and compared with two control treatments (without any additive and with a-tocopherol). Using $\mathrm{pH}$, lipid oxidation, microbiological, and sensory analyses, we monitored the changes in quality over 12 days of refrigerated storage.

\section{Materials and methods}

\subsection{Preparation of cephalopod skin pigment extracts}

Octopus (Octopus vulgaris) and squid (Dosidicus gigas) heads were acquired from local fishers on the coast of Hermosillo, Sonora, Mexico. The head skin, considered a by-product, was manually collected, freeze-dried (Labconco, Kansas City, MO, USA), and kept at $-18 \pm 2{ }^{\circ} \mathrm{C}$. Pigment extracts were prepared from $100 \mathrm{mg}$ of freeze-dried skin samples via extraction with $1 \% \mathrm{HCl}-$ methanol solution $(\mathrm{v} / \mathrm{v})$, as described elsewhere (Esparza-Espinoza et al., 2021). The samples without solvent were freeze-dried, packaged in polyethene bags, and stored at $-18 \pm 2{ }^{\circ} \mathrm{C}$.

\subsection{Antioxidant and antimutagenic activity of pigment extracts}

The in vitro antioxidant activity of the dried samples was determined using 2,2-diphenyl-1-picrylhydrazyl (DPPH) (Brand-Williams et al., 1995), 2,2' -azino-bis-(3-ethylbenzothiazoline6-sulfonic acid) (ABTS) (Re et al., 1999), and oxygen radical absorbance capacity (ORAC) (Prior et al., 2003) assays. The $\mathrm{DPPH}$ results were expressed as the percentage scavenging activity of $\mathrm{Abs}_{517}$ (RSA \%), and the ABTS and ORAC values were expressed as micromoles of Trolox (6-hydroxy-2,5,7,8tetramethylchroman-2-carboxylic acid) per gram of sample.

The antimutagenic potential of dried pigment extracts was determined by applying the Ames test (Maron \& Ames, 1983). Bioactivated (S9, Aroclor 1254-induced, Sprague-Dawley male rat liver in $0.154 \mathrm{M} \mathrm{KCl}$ solution) Salmonella typhimurium strains T98 and T100 were employed. A nutrient broth was used to generate bacteria $\left(1 \times 10^{9}\right.$ cells $/ \mathrm{mL}, 12 \mathrm{~h}$ culture, $\left.37^{\circ} \mathrm{C}\right)$, and aflatoxin $\mathrm{B}_{1}\left(\mathrm{AFB}_{1}\right.$; with $\left.\mathrm{S} 9 \mathrm{mix}\right)(500 \mathrm{ng} / \mathrm{mL})$ was used as the mutagen. For this assay, $100 \mu \mathrm{L}$ of pigment extract $(2.0,0.2,0.02$, and $0.002 \mathrm{mg} / \mathrm{mL}$ ) was combined in test tubes with $2 \mathrm{~mL}$ of top agar with L-histidine and D-biotin, S. typhimurium $(100 \mu \mathrm{L})$, and S9 enzymatic mix $(500 \mu \mathrm{L})$. The mixtures were quickly poured onto glucose minimal agar plates and incubated $\left(37^{\circ} \mathrm{C}, 48 \mathrm{~h}\right)$, and the His+ revertant colonies were counted. The inhibitory effect of the O. vulgaris and D. gigas skin ommochrome pigment extracts against $\mathrm{AFB}_{1}$ was expressed as the percentage inhibition of the mutagenicity caused by $500 \mathrm{ng}$ of pure $\mathrm{AFB}_{1}$ (Equation 1).

$\%$ Antimutagenicity $=\left(\frac{T R}{A F B_{1}-R}\right) \times 100$

where $T R$ is the number of treatment-induced revertants per plate, and $A F B_{1}-R$ is the number of Aflatoxin $\mathrm{B}_{1}$-induced revertants per plate (positive control).

The inhibition of $\mathrm{AFB}_{1}$ mutagenesis caused by the pigment extract was considered strong, moderate, or weak when the value was higher than $60 \%, 40 \%-60 \%$, or $20-40 \%$, respectively, and the effect was considered negligible when the value was less than 20\% (Ikken et al., 1999).

\subsection{Chicken burger preparation and sampling}

Raw chicken breast meat (moisture $73.6 \%$; protein $23.7 \%$; fat $1.5 \%$; ash $1.2 \%$ ) was purchased from a local market. The chicken material was cut aseptically by hand into strips and ground once through a stand mixer using a food grinder attachment with a coarse grinding plate having $5-\mathrm{mm}$ diameter orifices (model 251721, Apodaca, NL, Mexico). Burger were prepared by using ingredients reported in a commercial chicken burger data sheet, with some modification: ground chicken breast (97 g), corn starch ( $1 \mathrm{~g})$ and sodium chloride $(2 \mathrm{~g})$. Six batches (100 g/each) were then made: the control without any extract (CON); the control with $0.03 \%$ a-tocopherol (CET) (México, 2019); $0.05 \%$ octopus skin pigment extract added (OVE1); $0.1 \%$ octopus skin pigment extract added (OVE2); $0.05 \%$ squid skin pigment extract added (DGE1); and $0.1 \%$ squid skin pigment extract added (DGE2). Ground meat $(20 \mathrm{~g})$ was manually formed into disc-shaped patties ( $10 \mathrm{~cm}$ diameter and $1 \mathrm{~cm}$ thick) and aerobically packed in polyethylene bags and stored at $4{ }^{\circ} \mathrm{C}$ for 12 days. Burgers for each treatment were prepared in triplicate.

\section{Chemical analysis}

The $\mathrm{pH}$ values of the burgers were determined using a $\mathrm{pH}$ meter (Hanna HI 2211, Mexico) equipped with a puncture electrode (Association of Official Analytical Chemists, 1995). Lipid extraction was conducted by using a chloroform:methanol solvent system (1:1) (Bligh \& Dyer, 1959). Lipid extracts were evaporated and concentrated with a rotary evaporator (R-100, Büchi, Switzerland), and the extracted lipids were used for the formation of peroxidation-related compounds.

Peroxide values (PV) were evaluated as secondary peroxidation products according to Association of the Official Analytical Chemists methods (1995) with minor modification. The results were expressed as milliequivalents of peroxide oxygen per kilogram of the sample. The end-products of peroxidation (principally 2-alkenals) were determined using the $\mathrm{p}$-anisidine values ( $\mathrm{p}-\mathrm{AV}$ ) (International Union of Pure and Applied Chemistry, 1992). The p-AV was calculated using Equation 2.

$p-A V=\frac{25 \times(1.2 A s-A b)}{M}$ 
where $A s$ is the absorbance of the oil solution after reacting with p-AV, $A b$ is the absorbance of the oil solution, and $M$ is the sample mass (g). The overall oxidation state (TOTOX) value was calculated using Equation 3 (Pignitter \& Somoza, 2012).

TOTOX $=2 P V+p-A V$

\section{Microbiological analysis}

Ten grams of each sample was aseptically taken and mixed with $0.1 \% \mathrm{w} / \mathrm{v}$ peptone water $(90 \mathrm{~mL})$ in sterile stomacher bags; then, a ten-fold serial dilution was prepared. The dilution was blended using a vortex mixer (10 s), and each required dilution was aseptically plated and spread onto appropriate medium in a labelled Petri dish in triplicate using a Drigalski spatula. Microbial populations were counted using dilutions plated onto appropriate media: plate count agar was used for the total aerobic bacterial count (TBC) (incubation at $37^{\circ} \mathrm{C}, 48 \mathrm{~h}$ ); De Man, Rogosa and Sharpe agar was used for lactic acid bacteria (incubation at $37^{\circ} \mathrm{C}, 48 \mathrm{~h}$ ); Violet Red Bile Glucose agar was used for Enterobacteriaceae (incubation at $37^{\circ} \mathrm{C}, 48 \mathrm{~h}$ ); and Dichloran Rose-Bengal Chloramphenicol agar was used for molds and yeasts (incubation at $25^{\circ} \mathrm{C}, 5$ days). The colonies were counted using a colony counter (CVP-CM3 model, CScientific, Mexico City, Mexico) and expressed as the $\log _{10}$ of colony-forming units (CFU) per gram of chicken burger (Radhakrishnan et al., 2014).

\section{Sensory quality}

Sensory evaluations were performed using quantitative descriptive analysis (Stone, 1992). Six panellists (food technology postgraduate students; aged 25-40 years; 3 female and 3 male) were trained in six $30 \mathrm{~min}$ sessions. Three sensory attributes (brightness of color, animalic odor, and mucilage) were identified and defined by the panellists. Brightness of color refers to the color of the raw burger and ranged from light pink to dark pink. Animalic odor describes the aromatics that are reminiscent of chicken odor. Mucilage refers to a thick and gluey substance on the burger's surface. After the training sessions were completed, the six burger samples were evaluated by the six panelists by describing the above attributes. All raw samples were served simultaneously to each panelist after reaching room temperature. Each trained panellist was provided with one rectangular piece $(1.5 \times 2 \mathrm{~cm})$ of each burger type $(8 \mathrm{~g} / \mathrm{each})$; hence, there were a total of six pieces of burger and a hedonic evaluation sheet. After tasting each sample, the panellist selected one of the following five categories: highest quality (5), good quality (4), fair quality (3), poor quality (2), and unacceptable quality (1). The overall quality was expressed as mean values among panellists and descriptors in the samples, having the score that each panellist provided to each descriptor in each sample.

\subsection{Statistical analysis}

All measurements were run in triplicate. A wholly randomized, one-way analysis of variance (ANOVA) statistical design was carried out for the antioxidant activity, antimutagenic activity, chemical analysis, and microbiological analysis. The data obtained from the sensory evaluation assay were analyzed using a non-parametric Kruskal-Wallis test. Statistical significance was assessed using JMP 5.0.1 (SAS Institute, Inc., Cary, NC, USA). In all cases, the level of statistical significance was $p \leq 0.05$.

\section{Results and discussion}

\subsection{Biological activity of pigment extracts}

The pigment extracts obtained from octopus and squid skin had a reddish-violet color and a recovery yield of $0.25 \%$ and $0.11 \%$, respectively. Both extracts were capable of acting in vitro as antioxidant and antimutagenic compounds. DPPH reduction by antioxidants was $66 \%$ in OVE, and $58 \%$ in DGE, whereas reduction of the $\mathrm{ABTS}^{++}$radical generated $31.4 \mu \mathrm{mol}$ $\mathrm{TE} / \mathrm{g}$ in OVE and $26.7 \mu \mathrm{mol} \mathrm{TE} / \mathrm{g}$ in DGE. Similarly, the ORAC of OVE was $36.1 \mu \mathrm{mol} \mathrm{TE} / \mathrm{g}$ and that of DGE was $16.9 \mu \mathrm{mol} / \mathrm{g}$. The antioxidant activity of both pigments was considered effective for transferring hydrogen atoms since these values were higher than those for Trolox (a stable antioxidant) (30\%) measured by DPPH (Sacchetti et al., 2005) and for grape seed (14.7 $\mu \mathrm{mol} \mathrm{TE} / \mathrm{g}$ ) determined using ORAC (Bunea et al., 2012). The antioxidant capacity of certain natural compounds that prevent chicken burger lipid oxidation ranges from $92.6 \mu \mathrm{mol} / \mathrm{g}$ (grape seed) (Bunea et al., 2012) to $203 \mu \mathrm{mol} / \mathrm{g}$ (rosemary extracts) (Al-Hijazeen \& Al-Rawashdeh, 2019; Pereira et al., 2017) by ABTS. As a result, the ABTS value reflects the relative ability of electron-donating antioxidants in the extract to scavenge ABTS ${ }^{\circ}$.

The obtained pigments decreased the number of revertants per plate in a dose-response manner in S. typhimurium strains TA98 and TA100 (Figure 1). In both strains, pigments from the squid skin exhibited the highest activity. In TA100, the inhibition was considered moderate (40-60\%) at the lowest concentration tested $(0.002 \mathrm{mg} /$ plate $)$ and strong $(>60 \%)$ at $0.02 \mathrm{mg} /$ plate. In TA98, the inhibition was moderate when $0.2 \mathrm{mg}$ per plate was tested, whereas the OVE pigments showed effective inhibition of TA100 at $0.02 \mathrm{mg} /$ plate and of TA98 at $2 \mathrm{mg} /$ plate. Higher antimutagenic activity was detected in the present study compared to that obtained with methanolic extracts of octopus (P. limaculatus) tentacle by Cruz-Ramírez et al. (2015), who obtained $50 \%$ and $13 \%$ inhibition of $500 \mathrm{ng} \mathrm{AFB}_{1}$ with $0.05 \mathrm{mg} / \mathrm{mL}$

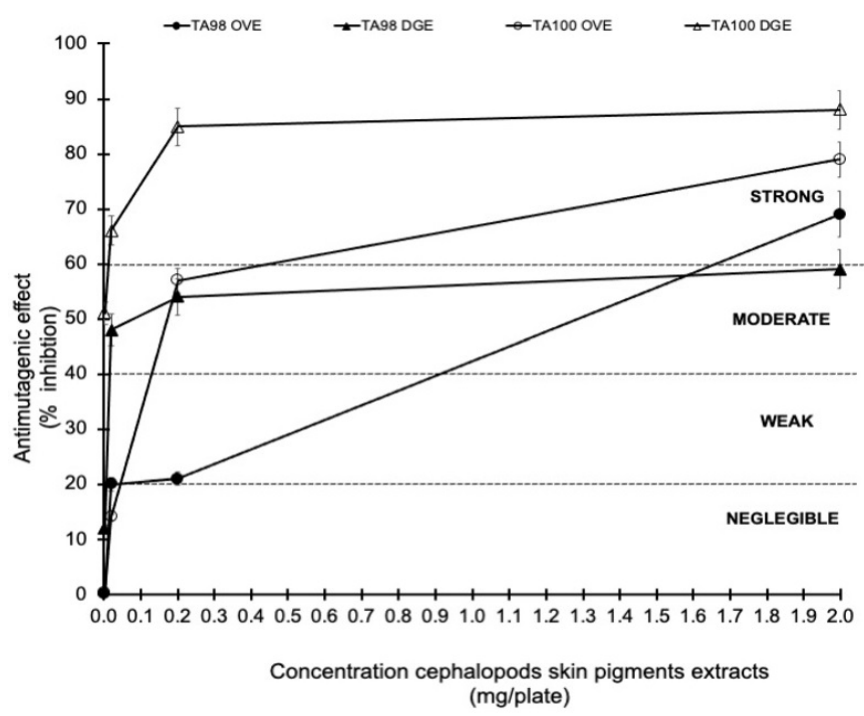

Figure 1. Effect of Octopus vulgaris and Dosidicus gigas skin pigment extracts on mutagenicity induced by $\mathrm{AFB}_{1}$, based on Salmonella typhimurium TA98 and TA100 assays. Results are represented as the percentage inhibition of $\mathrm{AFB}_{1}$ mutations ( $500 \mathrm{ng}$ ), with the mean values of three replicates \pm standard error. 
of extract when exposed to S. typhimurium strains TA98 and TA100, respectively. Since the mutagenic mechanism in $\mathrm{AFB}_{1}$ is mediated by the production of free radicals, which can lead to the disruption of chromosomes (Alpsoy et al., 2009), antioxidant molecules such as xanthommatin and dihydroxanthommatin can also act as antimutagens by preventing the formation of radicals (Chan-Higuera et al., 2019c) and the mutation of $S$. typhimurium by $\mathrm{AFB}_{1}$ (Chan-Higuera et al., 2019a).

\subsection{Chicken burger shelf life}

\section{Chemical analysis}

Chicken burgers are highly vulnerable to peroxidation and microbial growth due to the disruption of their cellular components. In the current work, a progressive increase in the $\mathrm{pH}$ value with refrigeration time $(p \leq 0.05)$ was observed for all treatments $\left(\mathrm{r}^{2}=0.86-0.96\right)$ (Figure $\left.2 \mathrm{~A}\right)$. The increase in $\mathrm{pH}$ detected may be related to the development of Gram-negative bacteria (Verma \& Sahoo, 2000), as observed in this work. Gram-negative bacteria cause the denaturation of proteins, leading to ammonia production; this metabolite induces an increase in $\mathrm{pH}$ (Verma \& Sahoo, 2000). The chicken burgers corresponding to OVE1 and DGE1 exhibited lower $\mathrm{pH}$ values than their negative (CON) and positive (CET) control counterparts in the 9-12-day period. The lower $\mathrm{pH}$ values of the chicken burgers submitted to OVE and DGE

(A)

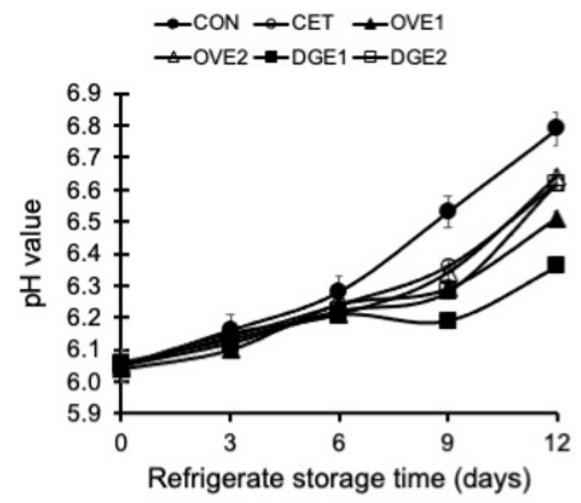

(C)

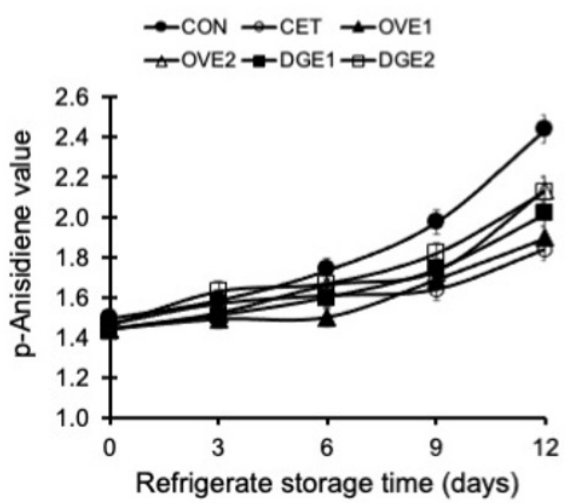

treatments is attributed to the antimicrobial ingredients found in the ommochrome pigment extracts (Chan-Higuera et al., 2019a).

Through the process of lipid oxidation, different molecules are generated. $\mathrm{PV}$ was used to estimate the propagation phase, and $\mathrm{p}$-AV was used to study the production of aldehydes during the oxidation of chicken burgers during storage. At the same time, the TOTOX value was employed as an indication of overall oxidative stability (Pignitter \& Somoza, 2012). Little formation of peroxide was observed in all kinds of chicken burger samples, with the PV being below 6.5 (Figure 2B). In most cases, a lower mean PV was determined in the chicken burger samples corresponding to the OVE1 treatment. The $\mathrm{p}-\mathrm{AV}$ showed a significant increase $(p \leq 0.05)$ with refrigeration time $\left(r^{2}=0.84-0.94\right)$, especially at the end of the storage period (Figure $2 \mathrm{C}$ ). As a general trend, the inhibitory effect $(p \leq 0.05)$ was higher in OVE1 and DGE1 throughout the entire experiment at a storage temperature of $4{ }^{\circ} \mathrm{C}(p \leq 0.05)$. Although the $\alpha$-tocopherol treatment resulted in a low $\mathrm{p}-\mathrm{AV}$ at the end of storage, no significant differences were detected compared to the OVE1 treatment $(p \geq 0.05)$. Moreover, when the TOTOX values were established, the addition of $0.05 \%$ OVE to the chicken burger (OVE1) remarkably induced the strongest inhibition of lipid oxidation (Figure 2D).

Previous studies have indicated that squid pigment extracts can be used to prevent lipid oxidation. The addition of $0.5 \%$ squid

(B)

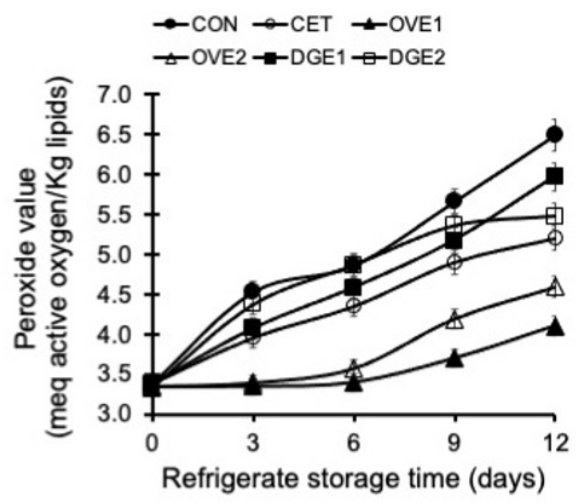

(D)

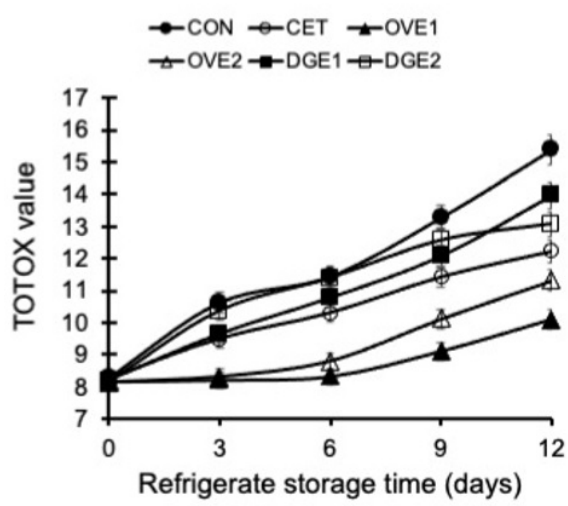

Figure 2. Evolution of $\mathrm{pH}$ and lipid damage in different chicken burgers during refrigerated storage $\left(4^{\circ} \mathrm{C}\right)$ : control without extract $(\mathrm{CON})$; control with $0.03 \%$ a-tocopherol (CET); $0.05 \%$ octopus skin pigment extract added (OVE1); 0.1\% octopus skin pigment extract added (OVE2); $0.05 \%$ squid skin pigment extract added (DGE1); $0.1 \%$ squid skin pigment extract added (DGE2). Results are the mean values of three replicates $(\mathrm{n}=3)$; standard deviations are indicated by bars. 
ethanolic pigment extract led to the enhancement of cod liver oil during storage (Aubourg et al., 2016), whereas inclusion at $0.1 \%$ in tuna pâté led to inhibition of PV (Chan-Higuera et al., 2019b). This behavior could be due to the presence of antioxidant compounds in the pigments, which may exert a certain level of lipid oxidation inhibition. This capacity is based on the configuration of ommochromic compounds present in the pigment extracts (Esparza-Espinoza et al., 2021). Ommochromes can act as free radical acceptors, thereby decreasing oxidation and forming new radicals in the oxidation process (Romero \& Martínez, 2015).

\section{Microbiological analysis}

The analysis of microorganisms causing food spoilage, as well as the pathogens that might harm human health, is essential for any food product. Among these microorganisms, Lactobacillus spp. have been associated with alteration of chicken meat when kept refrigerated (Zhang et al., 2016), whereas some bacteria belonging to the Enterobacteriaceae group are associated with consumer intoxication (D’Agostino \& Cook, 2016), and molds and yeasts have been established as an index of the sanitary quality of processed products (Tournas et al., 2001). Therefore, in this work, these microorganisms were selected as quality indicators.

The microbiological analysis showed that the total microflora counts for all treatments showed a progressive increase $(p \leq 0.05)$ as storage time progressed $\left(\mathrm{r}^{2}=0.87-0.97\right)$, as expected (Figure $3 \mathrm{~A}$ ). Remarkably, the inclusion of OVE and DGE pigments in the chicken burgers caused better TBC control compared to the control and $\alpha$-tocopherol treatments. The control samples reached or exceeded the values considered to be the upper limit acceptable for chicken products $\left(7.0 \log _{10} \mathrm{CFU} / \mathrm{g}\right.$ ) (Senter et al., 2000) on

(A)

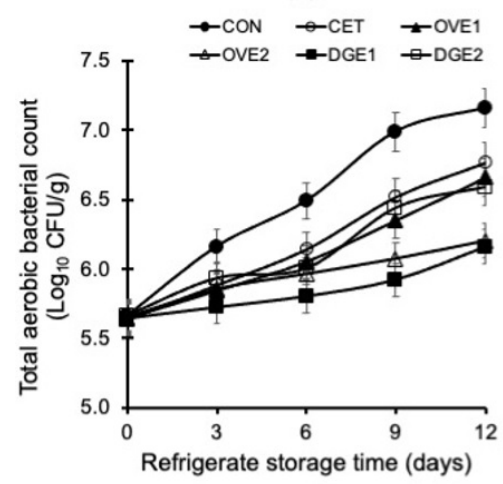

(C)

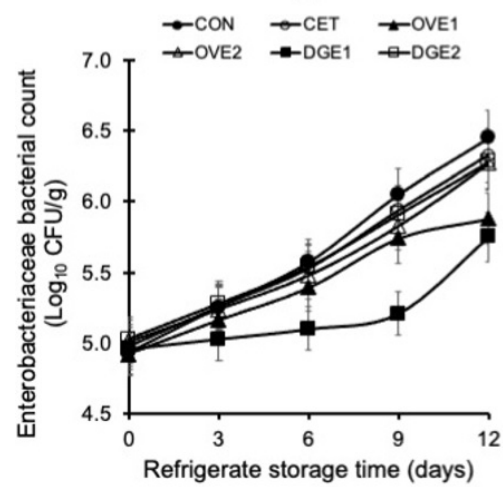

day 9 , while the samples containing ommochrome extracts never reached that limit. At the end of the storage period, a larger increase $(p \leq 0.05)$ of TBC $\left(1.51 \log _{10}\right.$ CFU/g) was observed in the $\mathrm{CON}$ chicken burgers compared to CET $\left(1.14 \log _{10} \mathrm{CFU} / \mathrm{g}\right)$, OVE1 (1.01 $\left.\log _{10} \mathrm{CFU} / \mathrm{g}\right)$, OVE2 (0.56 $\left.\log _{10} \mathrm{CFU} / \mathrm{g}\right)$, DGE1 (0.52 $\left.\log _{10} \mathrm{CFU} / \mathrm{g}\right)$, and DGE2 (0.93 $\left.\log _{10} \mathrm{CFU} / \mathrm{g}\right)$.

Lactobacillus growth (Figure 3B) did not reach values that could induce acidic odors or flavors (Zhang et al., 2016) in chicken burgers. Even the samples supplemented with the pigment extracts at $0.05 \%$ showed lower LAB growth $(p \leq 0.05)$ over days $4-9$ compared to the other treatments, especially CON. At the end of the storage period, the burgers corresponding to OVE1 and DGE1 treatments had $0.8 \log _{10}$ CFU/g less LAB than CON. The growth pattern of Enterobacteriaceae, facultative anaerobic bacteria, was similar to that of LAB (Figure 3 C), and the lowest counts ( $p \leq 0.05$ ) were obtained for the DGE1-treated samples. The final bacterial increases were $1.51,1.35,0.93,1.26,0.79$, and $1.25 \log _{10} \mathrm{CFU} / \mathrm{g}$ for the CON, CAT, OVE1, DGE2, DGE1, and OVE2 samples, respectively.

Analysis of molds and yeasts indicated a greater development of yeasts than of filamentous molds, which grew slower than the bacteria. This behavior is expected in high-humidity foods kept at low temperatures (Tournas et al., 2001). Notably, the addition of $0.05 \%$ DGE completely inhibited the growth of these microorganisms (Figure 3D). CET, OVE1, OVE2, and DGE2 also resulted in a significant $(p \leq 0.05)$ reduction in mold and yeast counts, with a final increase of $1.21,1.03,1.37$, and $0.31 \log _{10} \mathrm{CFU} / \mathrm{g}$, respectively, compared to $1.44 \log _{10} \mathrm{CFU} / \mathrm{g}$ for the control samples.

The effects derived from the presence of natural compounds with antimicrobial activity in chicken products have been reported.

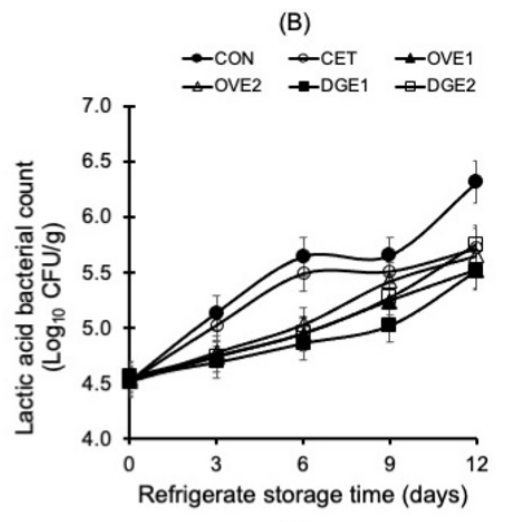

(D)

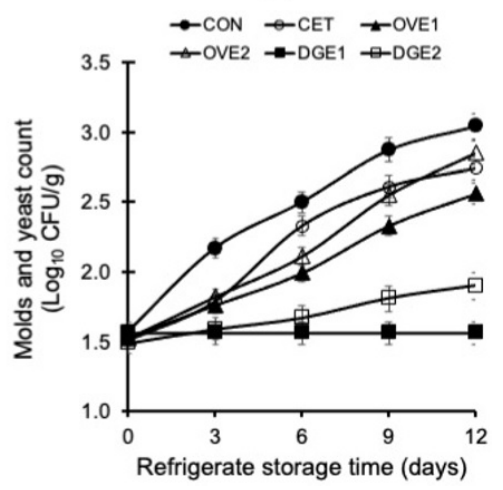

Figure 3. Evolution of microorganisms in different chicken burgers during refrigerated storage $\left(4{ }^{\circ} \mathrm{C}\right)$. Results are the mean values of three replicates $(\mathrm{n}=3)$; standard deviations are indicated by bars. Treatments (CON, CET, OVE1, OVE2, DGE1, and DGE2) are indicated in Figure 2. 
Such reports account mainly for the inclusion of herb and spice extracts in foods (Aziz \& Karboune, 2018). This is the first study that has proven the antimicrobial effects derived from the presence of methanolic extracts of octopus and squid ommochrome pigment in chicken burgers. A previous study investigated the preservative effects of acidified methanolic extracts of squid skin (Chan-Higuera et al., 2019b). In that work, an antimicrobial effect (lower aerobic mesophile counts) was observed during the refrigerated storage of tuna pâté. Extracts containing cephalopod pigments belonging to the ommochrome family (Deravi et al., 2014) were responsible for the microorganism behavior detected in this study (Chan-Higuera et al., 2019a). The mechanism of action for the antimicrobial activity of ommochromes has been attributed to their amphipathic nature, giving them the ability to interact with cell membrane components (Chan-Higuera et al., 2019a), as well as their electron-donor capacity, which might induce an imbalance in the metabolic pathways in microorganisms (Romero \& Martínez, 2015).
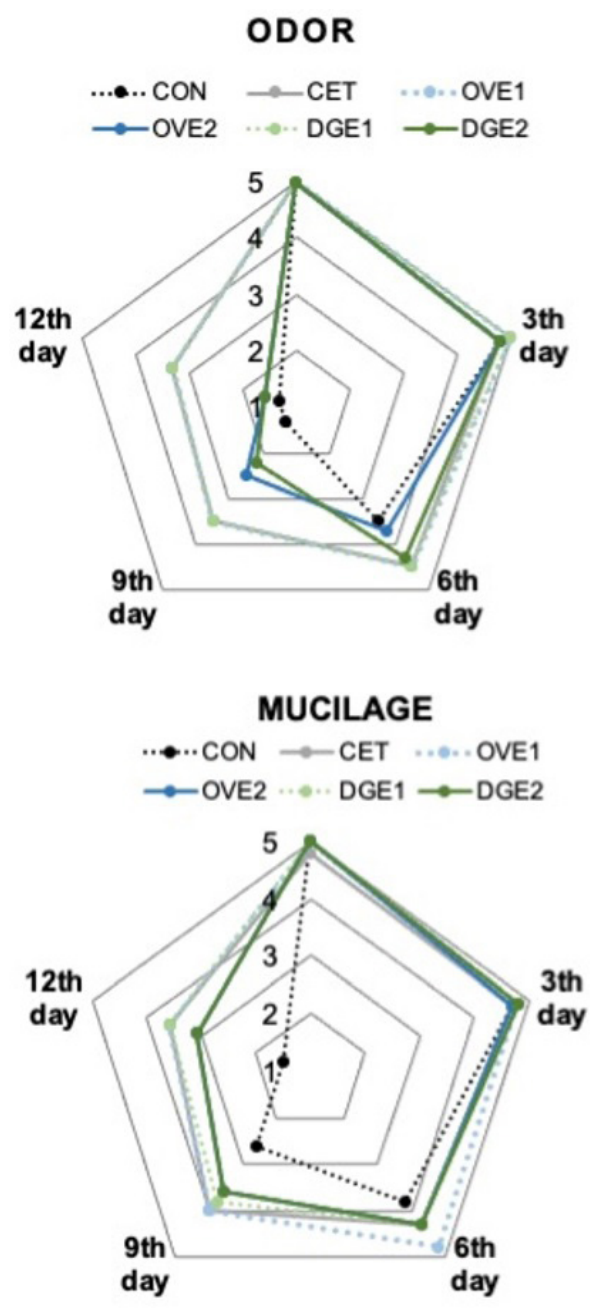

Sensory analysis

The excellent quality described for the initial chicken burger was progressively lost throughout refrigerated storage in all samples (Figure 4). Remarkably, the limiting acceptability score above 3.0 for different descriptors was never reached $(p \leq 0.05)$, even after 12 days, for the samples treated with $\alpha$-tocopherol and pigment extracts at $0.05 \%$. In contrast, the CON, OVE2 $(0.1 \%)$, and DGE2 $(0.1 \%)$ chicken burgers showed fair or poor-quality at this storage time. Indeed, strong animal odors were detected in the CON, OVE2, and DGE2 treatments after 12 days.

The low scores of the control and supplemented with $0.01 \%$ pigment extracts treatments after the ninth day of storage could be due to the production of an off-odor, induced by lipid oxidation or ammonia production. Similarly, another report described an improvement in the sensory quality of tuna pâté when a lower concentration of squid pigment extracts was added (Chan-Higuera et al., 2019a).
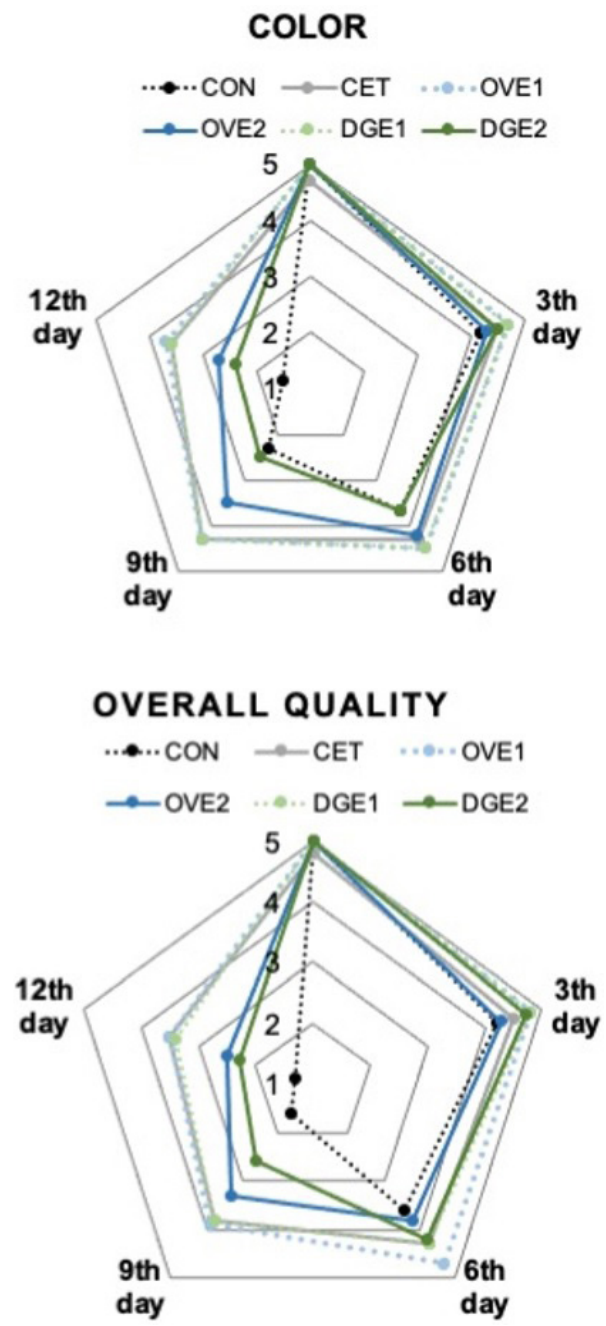

Figure 4. Spider diagram for the evolution of sensory evaluation of the different chicken burgers during refrigerated storage $\left(4^{\circ} \mathrm{C}\right)$. Score: highest quality (5), good quality (4), fair quality (3), poor quality (2), and unacceptable quality (1). Treatments (CON, CET, OVE1, OVE2, DGE1, and DGE2) are indicated in Figure 2. 
Our previous work established that $O$. vulgaris and D. gigas methanolic pigment extracts contain similar compounds, but different concentrations were suggested (Esparza-Espinoza et al., 2021). This difference could explain the diverse behaviors observed in the present study between the two pigment extracts. Moreover, the lower effectivities detected at higher concentration of the extracts could be attributed that the stability of any natural compounds can be affected by several factors, one of them the concentration employed (Ali et al., 2018). However, future work should focus on identifying and establishing the concentration of the main compounds present in the pigmented skin methanolic extracts from octopus and squid skin, as well the stability of the compounds associated with its concentration.

\section{Conclusions}

This study confirms that cephalopod skin pigment extracts could be a source of antioxidant and antimutagenic compounds. When both pigments were separately applied in the chicken burgers, the addition of $0.05 \%(\mathrm{w} / \mathrm{w})$ retarded lipid oxidation, inhibited microbial growth, and maintained the sensory qualities for 12 days. They were relatively comparable to $a$-tocopherol. Further works must evaluate the antioxidant and antimutagenic properties of raw and cooked chicken burgers containing different concentrations of cephalopod pigment extracts.

\section{Acknowledgements}

This work was supported by CONACyT-Mexico, grant 2174. Esparza-Espinoza was funded by a CONACyT grant from the Mexican Government. The authors would like to thank Jesús Enrique Chan-Higuera and Armando Burgos Hernández for their excellent technical assistance.

\section{References}

Al-Hijazeen, M., \& Al-Rawashdeh, M. (2019). Preservative effects of rosemary extract (Rosmarinus officinalis L.) on quality and storage stability of chicken meat patties. Food Science and Technology, 39(1), 27-34. http://dx.doi.org/10.1590/1678-457x.24817.

Ali, A., Chong, C. H., Mah, S. H., Abdullah, L. C., Choong, T. S. Y., \& Chua, B. L. (2018). Impact of storage conditions on the stability of predominant phenolic constituents and antioxidant activity of dried piper betle extracts. Molecules, 23(2), 484. http://dx.doi.org/10.3390/ molecules23020484. PMid:29473847.

Alpsoy, L., Yildirim, A., \& Agar, G. (2009). The antioxidant effect of vitamin $\mathrm{A}, \mathrm{C}$, and $\mathrm{D}$ on aflatoxin $\mathrm{B}_{1}$-induced oxidative stress in human lymphocytes. Toxicology and Industrial Health, 25(2), 121127. http://dx.doi.org/10.1177/0748233709103413. PMid:19458134.

Aryee, N. A., \& Boye, J. I. (2014). Current and emerging trends in the formulation and manufacture of nutraceuticals and functional food products. In J. I. Boye (Ed.), Nutraceutical and functional food processing and technology (pp. 1-60). New Jersey: John Wiley \& Sons, Ltd. http://dx.doi.org/10.1002/9781118504956.ch1.

Association of Official Analytical Chemists - AOAC. (1995). Official methods of analysis of the Association of Official Analytical Chemists. (16th ed). Washington: AOAC.

Aubourg, S. P., Torres-Arreola, W., Trigo, M., \& Ezquerra-Brauer, J. M. (2016). Partial characterisation of jumbo squid skin pigment extract and its antioxidant potential in a marine oil system. European
Journal of Lipid Science and Technology, 118(9), 1293-1304. http:// dx.doi.org/10.1002/ejlt.201500356.

Aziz, M., \& Karboune, S. (2018). Natural antimicrobial/antioxidant agents in meat and poultry products as well as fruits and vegetables: a review. Critical Reviews in Food Science and Nutrition, 58(3), 486511. PMid:27437876.

Bligh, E. G., \& Dyer, W. (1959). A rapid method of total lipid extraction and purification. Canadian Journal of Biochemistry and Physiology, 37(8), 911-917. http://dx.doi.org/10.1139/o59-099. PMid:13671378.

Brand-Williams, W., Cuvelier, M. E., \& Berset, C. (1995). Use of a free radical method to evaluate antioxidant activity. $L W T, 28(1), 25-30$. http://dx.doi.org/10.1016/S0023-6438(95)80008-5.

Bunea, C. I., Pop, N., Babes, A. C., Matea, C., Dulf, F. V., \& Bunea, A. (2012). Carotenoids, total polyphenols and antioxidant activity of grapes (Vitis vinifera) cultivated in organic and conventional systems. Chemistry Central Journal, 6(1), 66. http://dx.doi.org/10.1186/1752153X-6-66. PMid:22762349.

Chan-Higuera, J. E., Carbonell-Barrachina, A. A., Cárdenas-López, J. L., Kačániová, M., Burgos-Hernández, A., \& Ezquerra-Brauer, J. M. (2019a). Jumbo squid (Dosidicus gigas) skin pigments: chemical analysis and evaluation of antimicrobial and antimutagenic potential. Journal of Microbiology, Biotechnology and Food Sciences, 9(2), 349353. http://dx.doi.org/10.15414/jmbfs.2019.9.2.349-353.

Chan-Higuera, J. E., Ezquerra-Brauer, J. M., Lipan, L., Cano-Lamadrid, M., Rizzitano, R., \& Carbonell-Barrachina, A. A. (2019b). Evaluation of Dosidicus gigas skin extracts as an antioxidant and preservative in tuna pâté. Foods, 8(12), 693. http://dx.doi.org/10.3390/foods8120693. PMid:31861248.

Chan-Higuera, J. E., Santacruz-Ortega, H. D. C., Carbonell-Barrachina, Á. A., Burgos-Hernández, A., Robles-Sánchez, R. M., Cruz-Ramírez, S. G., \& Ezquerra-Brauer, J. M. (2019c). Xanthommatin is behind the antioxidant activity of the skin of Dosidicus gigas. Molecules, 24(19), 3420. http://dx.doi.org/10.3390/molecules24193420. PMid:31547094.

Cruz-Ramírez, S. G., López-Saiz, C. M., Rosas-Burgos, E. C., CincoMoroyoqui, F. J., Velázquez, C., Hernández, J., \& Burgos-Hernández, A. (2015). Antimutagenic, antiproliferative, and antioxidant effect of extracts obtained from octopus (Paraoctopus limaculatus). Food Science and Technology, 35(4), 722-728. http://dx.doi.org/10.1590/1678457X.0001.

D’Agostino, M., \& Cook, N. (2016). Foodborne pathogens. In B. Caballero, P. M. Finglas, \& F. Toldrá (Eds.), Encyclopedia of food and health (2nd ed., pp. 83-86). Cambridge: Academic Press. http:// dx.doi.org/10.1016/B978-0-12-384947-2.00326-3 .

Daniels, E. V., \& Reed, R. D. (2012). Xanthurenic acid is a pigment in Junonia coenia butterfly wings. Biochemical Systematics and Ecology, 44, 161-163. http://dx.doi.org/10.1016/j.bse.2012.04.025.

Deravi, L. F., Magyar, A. P., Sheehy, S. P., Bell, G. R., Mäthger, L. M., Senft, S. L., Wardill, J., Lane, W. S., Kuzirian, A. M., Hanlon, R. T., Hu, E. L., \& Parker, K. K. (2014). The structure-function relationships of a natural nanoscale photonic device in cuttlefish chromatophores. Journal of the Royal Society, Interface, 11(93), 20130942. http:// dx.doi.org/10.1098/rsif.2013.0942. PMid:24478280.

Esparza-Espinoza, D. M., Santacruz-Ortega, H. C., Chan-Higuera, J. E., Cárdenas-López, J. L., Burgos-Hernández, A., Carbonell-Barrachina, A. A., \& Ezquerra-Brauer, J. M. (2021). Chemical structure and antioxidant activity of cephalopod skin ommochrome pigment extracts. Food Science and Technology. Ahead of print.

Ezquerra-Brauer, J. M., Miranda, J., Cepeda, A., Barros-Velázquez, J., \& Aubourg, S. (2016). Effect of jumbo squid (Dosidicus gigas) skin extract on the microbial activity in chilled mackerel (Scomber scombrus). LWT, 72, 134-140. http://dx.doi.org/10.1016/j.lwt.2016.04.024. 
Ezquerra-Brauer, J. M., Miranda, J., Chan-Higuera, J., Barros-Velázquez, J., \& Aubourg, S. (2017). New icing media for quality enhancement of chilled hake (Merluccius merluccius) using a jumbo squid (Dosidicus gigas) skin extract. Journal of the Science of Food and Agriculture, 97(10), 3412-3419. http://dx.doi.org/10.1002/jsfa.8192. PMid:28009054.

Ikken, Y., Morales, P., Martinez, A., Marin, M. L., Haza, A. I., \& Cambero, M. I. (1999). Antimutagenic effect of fruit and vegetable ethanolic extracts against $\mathrm{N}$-nitrosamines evaluated by the Ames test. Journal of Agricultural and Food Chemistry, 47(8), 3257-3264. http://dx.doi. org/10.1021/jf990166n. PMid:10552641.

International Union of Pure and Applied Chemistry - IUPAC. (1992). Standard methods for the analysis of oils and fats and derivatives: determination of the $p$-anisidine value ( $p$-A.V.) of the International Union of Pure and Applied Chemistry, Applied Chemistry Division, Commission on Oils, Fats and Derivatives (7th ed., Section 2.504). Oxford: Blackwell Scientific Publishing.

Kumar, Y., Kaur, K., Shahi, A. K., Kairam, N., \& Tyagi, S. K. (2017). Antilisterial, antimicrobial and antioxidant effects of pediocin and Murraya koenigii berry extract in refrigerated goat meat emulsion. LWT, 79, 135-144. http://dx.doi.org/10.1016/j.lwt.2017.01.028.

Maron, D. M., \& Ames, B. N. (1983). Revised methods for the Salmonella mutagenicity test. Mutation Research, 113(3-4), 173-215. http:// dx.doi.org/10.1016/0165-1161(83)90010-9. PMid:6341825.

México, Secretaria de Gobernación, Secretaria de Salud. (2019). NORMA Oficial Mexicana NOM-213-SSA1-2018, Productos y servicios. Productos cárnicos procesados y los establecimientos dedicados a su proceso (DOF:03/04/2019). Diario Oficial de la Federación de los Estados Unidos Mexicanos.

Ostrovsky, M. A., Sakina, N. L., \& Dontsov, A. E. (1987). An antioxidative role of ocular screening pigments. Vision Research, 27(6), 893-899. http://dx.doi.org/10.1016/0042-6989(87)90005-8. PMid:3499029.

Peng, C., Wang, X., Chen, J., Jiao, R., Wang, L., Li, Y. M., Zuo, Y., Liu, Y., Lei, L., Ma, K. Y., Huang, Y., \& Chen, Z. Y. (2014). Biology of ageing and role of dietary antioxidants. BioMed Research International, 2014, 831841. http://dx.doi.org/10.1155/2014/831841. PMid:24804252.

Pereira, D., Pinheiro, R. S., Heldt, L. F. S., Moura, C., Bianchin, M., Almeida, J. F., Reis, A. S., Ribeiro, I. S., Haminiuk, C. W. I., \& Carpes, S. T. (2017). Rosemary as natural antioxidant to prevent oxidation in chicken burger. Food Science and Technology, 37(Suppl. 1), 17-23. http://dx.doi.org/10.1590/1678-457x.31816.

Pignitter, M., \& Somoza, V. (2012). Critical evaluation of methods for the measurement of oxidative rancidity in vegetables oils. Yao Wu Shi Pin Fen Xi, 20(4), 772-777. http://dx.doi.org/10.6227/jfda.2012200305.

Prior, R. L., Hoang, H., Gu, L., Wu, X., Bacchiocca, M., Howard, L., Hampsch-Woodill, M., Huang, D., Ou, B., \& Jacob, R. (2003). Assays for hydrophilic and lipophilic antioxidant capacity (oxygen radical absorbance capacity (ORACFL) of plasma and other biological and food samples. Journal of Agricultural and Food Chemistry, 51(11), 3273-3279. http://dx.doi.org/10.1021/jf0262256. PMid:12744654.

Radhakrishnan, K., Babuskin, S., Babu, P. A. S., Sasikala, M., Sabina, K., Archana, G., Sivarajan, M., \& Sukumar, M. (2014). Antimicrobial and antioxidant effects of spice extracts on the shelf life extension of raw chicken meat. International Journal of Food Microbiology, 171, 32-40. http://dx.doi.org/10.1016/j.ijfoodmicro.2013.11.011. PMid:24308943.

Ramsing, B. (2020). Food trends for 2020 show a sustainability focus. Baltimore: Johns Hopkins Center for a Livable Future. Retrieved from https://clf.jhsph.edu/viewpoints/food-trends-2020-showsustainability-focus.

Re, R., Pellegrini, N., Proteggente, A., Pannala, A., Yang, M., \& RiceEvans, C. (1999). Antioxidant activity applying an improved ABTS radical cation decolorisation assay. Free Radical Biology \& Medicine, 26(9-10), 1231-1237. http://dx.doi.org/10.1016/S0891-5849(98)003153. PMid:10381194.

Romero, Y., \& Martínez, A. (2015). Antiradical capacity of ommochromes. Journal of Molecular Modeling, 21(8), 220. http://dx.doi.org/10.1007/ s00894-015-2773-3. PMid:26238086.

Sacchetti, G., Maietti, S., Muzzoli, M., Scaglianti, M., Manfredini, S., Radice, M., \& Bruni, R. (2005). Comparative evaluation of 11 essential oils of different origin as functional antioxidants, antiradicals and antimicrobials in foods. Food Chemistry, 91(4), 621-632. http:// dx.doi.org/10.1016/j.foodchem.2004.06.031.

Senter, S. D., Arnold, J. W., \& Chew, W. (2000). APC values and volatiles compounds formed in commercially processed, raw chicken parts during storage at 4 and $13{ }^{\circ} \mathrm{C}$ under simulated temperature abuse conditions. Journal of the Science of Food and Agriculture, 80(10), 15591564. http://dx.doi.org/10.1002/1097-0010(200008)80:10<1559::AIDJSFA686>3.0.CO;2-8.

Shahidi, F., Varatharajan, V., Peng, H., \& Senadheera, R. (2019). Utilization of marine by-products for the recovery of value-added products. Journal of Food Bioactives, 6, 10-61. http://dx.doi.org/10.31665/ JFB.2019.5183.

Stone, H. (1992). Quantitative descriptive analysis (QDA). In R. C. Hootman (Ed.), Manual on descriptive analysis testing for sensory evaluation (pp. 15-21). Philadelphia: ASTM International. Retrieved from https://pdfs.semanticscholar.org/542e/97e9172ec8575b7e875 24fb2ff8eeb095dad.pdf.

Tournas, V., Stack, M. E., Mislivec, P. B., Koch, H. A., \& Bandler, R. (2001). Yeasts, molds and mycotoxins. In Bacteriological analytical manual (Chap. 18). Maryland: U. S. Food and Drug Administration. Retrieved from https://www.fda.gov/food/laboratory-methods-food/ bacteriological-analytical-manual-bam.

Verma, S. P., \& Sahoo, J. (2000). Improvement in the quality of ground chevron during refrigerated storage by tocopherol acetate preblending. Meat Science, 56(4), 403-413. http://dx.doi.org/10.1016/S03091740(00)00072-3. PMid:22062171.

Zhang, H., Wu, J., \& Guo, X. (2016). Effects of antimicrobial and antioxidant activities of spice extracts on raw chicken meat quality. Food Science and Human Wellness, 5(1), 39-48. http://dx.doi. org/10.1016/j.fshw.2015.11.003. 